\title{
PNEUMOPERITONEUM AFTER PERINEAL PROCTOSIGMOIDECTOMY (ALTAMEIR PROCEDURE)
}

\author{
Audel Pedroza Ballesteros ${ }^{1}$ \\ ${ }^{1}$ Universidad El Bosque
}

January 23, 2022

\begin{abstract}
A 77-year-old female patient was taken to surgery for correction of complete rectal prolapse. On the first postoperative day the patient presented severe generalized abdominal pain, with no other symptoms. 1. An abdominal CT scan was performed,
\end{abstract} which showed pneumoperitoneum and air near the coloanal anastomosis

PNEUMOPERITONEUM AFTER PERINEAL PROCTOSIGMOIDECTOMY.

Summary

Rectal prolapse is defined as the exit of the lower part of the bowel through the anus on straining, mainly in older people, which must be corrected to avoid complications such as pain, ulcers, bleeding and fecal incontinence, although it is not free of complications.

A 77-year-old female patient was taken to surgery for correction of complete rectal prolapse. On the first postoperative day the patient presented severe generalized abdominal pain, with no other symptoms. Blood count was normal and arterial blood gases were normal. An abdominal CT scan was performed, which showed pneumoperitoneum and air near the coloanal anastomosis. On the 2nd postoperative day she was taken to emergency surgery without finding any perforation of hollow viscera or free intra-abdominal fluid. Pneumatic test of the coloanal anastomosis was performed and it was positive for air leakage. Peritoneal lavage and protective ileostomy were performed. She was discharged on the 5 th postoperative day, tolerated orally and without any additional complications. She is scheduled for ileostomy closure in the next few weeks.

Presentation of the case

A 77-year-old patient with a history of rectal prolapse of 5 years of evolution with a medical history of total abdominal hysterectomy and correction of rectal prolapse 2 years ago by perineal route as well (figure 1 ) Physical examination revealed a $5 \mathrm{~cm}$ rectal prolapse. It was decided to perform another rectal prolapse correction via perineal route with the altameir technique, which was performed without complications. Due to severe abdominal pain, an abdominal tomography was taken which showed pneumoperitoneum at 24 hours postoperatively(figure 2 and 3). Exploratory laparotomy was performed on the 2nd postoperative day with evidence of air leakage at the anastomosis level, without perforation of additional organs. Protective ileostomy was performed, presenting good postoperative evolution and discharged on postoperative day 5 .

\section{Perineal proctosigmoidectomy (altameir surgery)}

Rectal prolapse occurs when the walls of the rectum protrude through the anal orifice, mainly in older women $(1,2)$, mainly with a history of multiple pregnancies, previous surgeries such as hysterectomies, pelvic floor problems. Chronic obstructive disease or cystic fibrosis. Which produces pelvic floor problems and fecal 
incontinence, pelvic pain, rectal bleeding or ulceration(3), the only solution is prolapse correction surgery. There are more than 100 procedures described to correct prolapse, but there is no preferred method for prolapse correction. It can be corrected ab abdominally or perineally or a combination of the two depending on the patient's physical condition or anesthetic risk. Perineal proctosigmoidectomy is performed in older patients with high anesthetic risks obviating the need for a median laparotomy $(4,5)$. Although it presents few complications, anastomotic fistulas, postoperative bleeding, postoperative impaction, stenosis or recurrence can $\operatorname{occur}(6,7)$.

Discussion

The perineal correction technique consists of a circumferential incision of the entire rectal wall, the entire prolapsed tissue is removed, the intestine is divided and removed and the anastomosis is performed at $1 \mathrm{~cm}$ from the pectineal line with stitches separated with $2-0$ vicryl $(8,9)$. This could have generated a point of dehiscence generating the development of pneumoperitoneum, therefore it is necessary to exclude other pathologies such as perforations of the hollow viscera that could explain this complication (10), in this case the performance of a protective ileostomy helped the anastomosis to improve in the following weeks without complications, the insertion of a drain at pelvic level was not necessary(11).

Bibliography

1. Madiba TE, Baig MK, Wexner SD. Surgical management of rectal prolapse. Arch Surg. 2005;140(1):63-73.

2. Sailer M, Bönicke L, Petersen S. [Surgical options in the treatment of rectal prolapse: indications, techniques and results]. Zentralbl Chir. 2007;132(4):350-7.

3. Fang SH, Cromwell JW, Wilkins KB, Eisenstat TE, Notaro JR, Alva S, et al. Is the abdominal repair of rectal prolapse safer than perineal repair in the highest risk patients? An NSQIP analysis. Dis Colon Rectum. 2012;55(11):1167-72.

4. Whitlow CB, Beck DE, Opelka FG, Gathright JB, Jr., Timmcke AE, Hicks T. Perineal repair of rectal prolapse. J La State Med Soc. 1997;149(1):22-6.

5. Ding JH, Canedo J, Lee SH, Kalaskar SN, Rosen L, Wexner SD. Perineal rectosigmoidectomy for primary and recurrent rectal prolapse: are the results comparable the second time? Dis Colon Rectum. 2012;55(6):66670.

6. Steele SR, Goetz LH, Minami S, Madoff RD, Mellgren AF, Parker SC. Management of recurrent rectal prolapse: surgical approach influences outcome. Dis Colon Rectum. 2006;49(4):440-5.

7. Fleming FJ, Kim MJ, Gunzler D, Messing S, Monson JR, Speranza JR. It's the procedure not the patient: the operative approach is independently associated with an increased risk of complications after rectal prolapse repair. Colorectal Dis. 2012;14(3):362-8.

8. Altomare DF, Binda G, Ganio E, De Nardi P, Giamundo P, Pescatori M. Long-term outcome of Altemeier's procedure for rectal prolapse. Dis Colon Rectum. 2009;52(4):698-703.

9. Zbar AP, Takashima S, Hasegawa T, Kitabayashi K. Perineal rectosigmoidectomy (Altemeier's procedure): a review of physiology, technique and outcome. Tech Coloproctol. 2002;6(2):109-16.

10. Prêtre R, Robert J, Mirescu D, Witzig JA, Rohner A. Pathophysiology, recognition and management of pneumoretroperitoneum. Br J Surg. 1993;80(9):1138-40.

11. Mantoo S, Meurette G, Lehur PA. Re: It's the procedure not the patient: the operative approach is independently associated with an increased risk of complications after rectal prolapse repair. Colorectal Dis. $2012 ; 14(7): 897$.

\section{Hosted file}


Title Page.docx available at https://authorea.com/users/456800/articles/553784pneumoperitoneum-after-perineal-proctosigmoidectomy-altameir-procedure

\section{Hosted file}

figure 1.docx available at https://authorea.com/users/456800/articles/553784pneumoperitoneum-after-perineal-proctosigmoidectomy-altameir-procedure

\section{Hosted file}

figure2. docx available at https ://authorea.com/users/456800/articles/553784-pneumoperitoneumafter-perineal-proctosigmoidectomy-altameir-procedure

\section{Hosted file}

figure3.docx available at https://authorea.com/users/456800/articles/553784-pneumoperitoneumafter-perineal-proctosigmoidectomy-altameir-procedure 